\title{
Microstructure and mechanical behavior at elevated temperatures of a novel nickel base superalloy heavily alloyed with $\gamma^{\prime}$ forming and substitution elements
}

\author{
R. I. Zainullin', A. A. Ganeev², R. V. Shakhov², A. V. Logunov³, \\ Sh. Kh. Mukhtarov' 2 V. M. Imayev ${ }^{\dagger, 2}$ \\ †vimayev@mail.ru
}

${ }^{1}$ Ufa State Aviation Technical University, 12 K. Marx St., Ufa, 450008, Russia

${ }^{2}$ Institute for Metals Superplasticity Problems RAS, 39 S. Khalturin St., Ufa, 450001, Russia

${ }^{3}$ PJSC “UEC-Saturn”, 163 Lenina Av., Rybinsk, 152903, Russia

\begin{abstract}
A novel nickel base superalloy heavily alloyed with $\gamma^{\prime}$ forming and substitution elements, particularly with rhenium and tungsten, has been proposed in the present work as a potential die material for die forging of the most hard-to-deform nickel base superalloys. The superalloy composition is $\mathrm{Ni}-13(\mathrm{Al}, \mathrm{Ti}, \mathrm{Nb}, \mathrm{Ta})-27(\mathrm{Cr}, \mathrm{Co}, \mathrm{Mo}, \mathrm{W}, \mathrm{Re}, \mathrm{Si}, \mathrm{C}, \mathrm{B})$ (wt.\%). The superalloy ingot was manufactured by vacuum induction melting. Microstructure examination showed that the as-cast condition was characterized by a coarse grained dendritic structure consisted of coarse $\gamma$ grains containing $\gamma^{\prime}$ precipitates with a size $0.3-1 \mu \mathrm{m}$ and primary $\gamma^{\prime}$ particles with a size 5-100 $\mu \mathrm{m}$. A small amount of carbides and topologically close packed (TCP) phases was also detected. The microstructure examination suggests that the general solidification pathway was $L \rightarrow \gamma \rightarrow \gamma^{\prime}$, as it is in nickel base superalloys. At the same time, the primary $\gamma^{\prime}$ particles were probably formed via the peritectic reaction $L_{\text {noneq }}+\gamma \rightarrow \gamma^{\prime}$, where $L_{\text {noneq. }}$ is the nonequilibrium liquid, which was retained at the peritectic temperature. The superalloy was subjected to heat treatment including solid solution treatment and ageing. The heat treatment led to coagulation of the primary $\gamma^{\prime}$ phase and to a slight decrease in the volume fractions of carbides and TCP phases. The heat treated condition was used to prepare samples for compression tests, which were performed at $900-1200^{\circ} \mathrm{C}$ up to the true strain $e=0.1$. The yield strength of the novel superalloy was generally appreciably higher as compared with those of known nickel base superalloys and alloys based on the $\mathrm{Ni}_{3} \mathrm{Al}$ intermetallic phase.
\end{abstract}

Keywords: nickel base superalloys, $\gamma^{\prime}$ phase, topologically close packed phase, heat treatment, microstructure, mechanical properties.

\section{Introduction}

Nickel base superalloys are widely used as structural materials in gas turbine engines (GTE). To improve the fuel efficiency of GTE, it is of great importance to develop new nickel based superalloys, which can withstand higher operating temperatures and loadings $[1,2]$. However, the critical structural components made of heavily alloyed nickel base superalloys of last generation are typically produced via hot working (hot forging) at temperatures as high as $1100-1200^{\circ} \mathrm{C}$ to achieve properly balanced mechanical properties [1]. This means that the die forging material must be suitable for operation temperatures up to $1200^{\circ} \mathrm{C}$. One way, of course, is associated with using lower die temperature and encapsulating the forged workpiece in a specially designed can to provide quasi-isothermal conditions of hot forging. By this technique a lower die temperature can be used. However, this requires consumables and is rather laborious because canning and decanning of the forged workpiece [3-5]. Another way is to use Mo-based dies and a protective atmosphere that is also rather expensive [1]. Russian so called VKNA alloys based on the $\gamma^{\prime}\left(\mathrm{Ni}_{3} \mathrm{Al}\right)$ phase might be suitable for using as a die material in the temperature range of $1000-1200^{\circ} \mathrm{C}[6,7]$. However, operating temperatures for forging dies made of these alloys should be not less than $1000^{\circ} \mathrm{C}$ because these materials have rather low yield strength below this temperature. In addition, an issue is fabrication of high-quality massive dies made of the VKNA alloys.

The present work was devoted to a study of microstructure and compression behavior of a novel nickel base superalloy heavily alloyed with $\gamma^{\prime}$ forming elements and substitution elements, particularly rhenium and tungsten, and intended for using as a die material at operating temperatures $1000-1200^{\circ} \mathrm{C}$. The yield strength values obtained for the novel superalloy were compared with those of some creep resistant nickel base superalloys and the VKNA alloys.

\section{Material and experimental}

The experimental nickel base superalloy with a nominal chemical composition Ni-13(Al, Ti, Nb, Ta)-27(Cr, Co, Mo, $\mathrm{W}, \mathrm{Re}, \mathrm{Si}, \mathrm{C}, \mathrm{B}$ ) (in wt.\%) was manufactured by vacuum 
induction melting. The ingot material was subjected to longterm homogenization heat treatment, solid solution heat treatment at $1290^{\circ} \mathrm{C}$ followed by two-stage ageing at 1050 and $950^{\circ} \mathrm{C}$. The heat treated material was used to cut samples with a size of $\varnothing 8 \times 12 \mathrm{~mm}$ for compression tests, which were performed in the temperature range of $900-1200^{\circ} \mathrm{C}$ up to the strain value $e=0.1$.

Microstructure examination was carried out using scanning electron microscopy in backscattering electron mode (SEM, BSE). Before study by SEM, the specimen surfaces were polished. Electron backscatter diffraction (EBSD) analysis was performed for the as-cast condition with a scan-step size of $10 \mu \mathrm{m}$. EBSD analysis was conducted using the CHANNEL 5 processing software. The grain boundaries having misorientation angle less than $2^{\circ}$ were excluded from the consideration taking into account the measurement accuracy. The grain boundaries were assumed as high-angle ones if their misorientation angle was more than $15^{\circ}$.

\section{Results and Discussion}

Fig. 1 represents the BSE images of the as-cast ingot. One can see that a typical dendritic microstructure was obtained (Fig. 1a). The microstructure consisted of coarse $\gamma$ grains containing dispersed $\gamma^{\prime}$ precipitates with a size $0.3-1 \mu \mathrm{m}$, coarse primary $\gamma^{\prime}$ particles with a size 5-100 $\mu \mathrm{m}$, white carbides and TCP phases (Fig. 1a,b). The volume fraction of the carbides and the TCP phases was $1.5-2 \%$. The volume fraction of the coarse primary $\gamma^{\prime}$ particles was evaluated as about $10 \%$ (Fig. 1a). It should be emphasized that the dispersed $\gamma^{\prime}$ precipitates were uniformly distributed throughout the material (Fig. 1c) (with the exception of coarse primary $\gamma^{\prime}$ particles) that is typical of nickel base superalloys. Reasoning from this, one can conclude that the general solidification pathway was $L \rightarrow \gamma \rightarrow \gamma^{\prime}$, as it takes place in nickel base superalloys. At the same time, the observed coarse particles of the $\gamma^{\prime}$ phase were probably formed via the peritectic reaction $L_{\text {noneq. }}+\gamma \rightarrow \gamma^{\prime}$, where $L_{\text {noneq. }}$ is the nonequilibrium liquid, which was retained at the peritectic temperature [8-11]. Note that nonequilibrium eutectic $\gamma+\gamma^{\prime}$ colonies resulted from dendritic segregation were not detected in the as-cast condition.

Fig. 2 shows the BSE images of the superalloy in the heat treated condition. One can see that the dendritic structure disappeared. The heat treatment led to coagulation of the primary $\gamma^{\prime}$ phase particles and an increase its volume fraction. The size of the coarse primary $\gamma^{\prime}$ particles was $20-300 \mu \mathrm{m}$, the volume fraction was found to be about $15 \%$. The heat treatment resulted in a slight decrease in the volume fractions of carbides and TCP phases, which was defined as $1-1.5 \%$. Fine $\gamma^{\prime}$ precipitates were found to be more round than in the as-cast condition, their size was $0.5-1 \mu \mathrm{m}$ (Fig. 2 c). Fine white particles observed along boundaries of small $\gamma^{\prime}$ precipitates were probably the carbides precipitating during ageing (Fig. 2c) [3]. EBSD analysis of the heat treated condition confirmed that the $\gamma$ grain size was rather coarse $\left(d_{\gamma} \sim 1 \mathrm{~mm}\right)$ (Fig. 3).

Fig. 4 shows the true stress-true strain curves obtained as a result of compression tests of superalloy samples in the heat treated condition. For comparison the true stress-true strain curves are also shown for the heavily alloyed rhenium containing superalloy SDZhS-15 subjected to preliminary homo- and heterogenization heat treatment [3]. One can see that the flow stresses of the novel superalloy were appreciably higher than those of the SDZhS-15 superalloy.

Table 1 represents the yield strength values obtained for the novel superalloy in comparison with some nickel base superalloys and the VKNA alloys based on the $\mathrm{Ni}_{3} \mathrm{Al}$ intermetallic phase. Note that the ZhS6U superalloy and VKNA alloys are used as die forging materials. One can

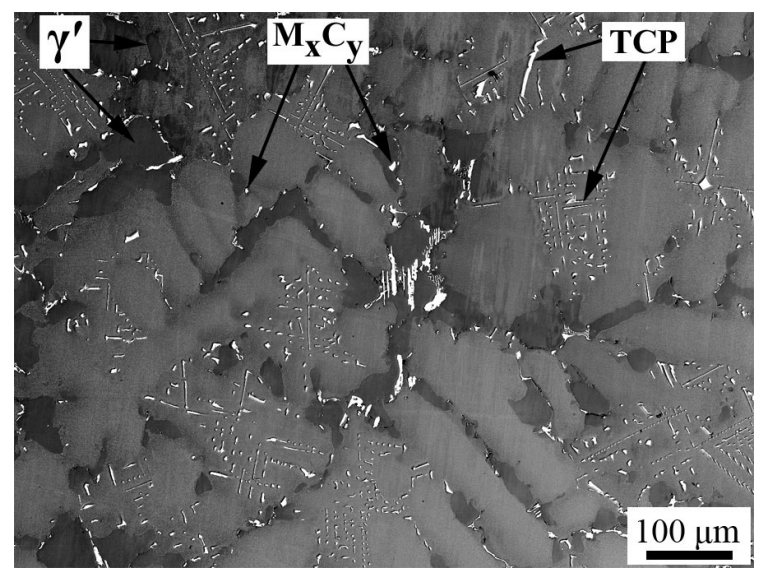

a

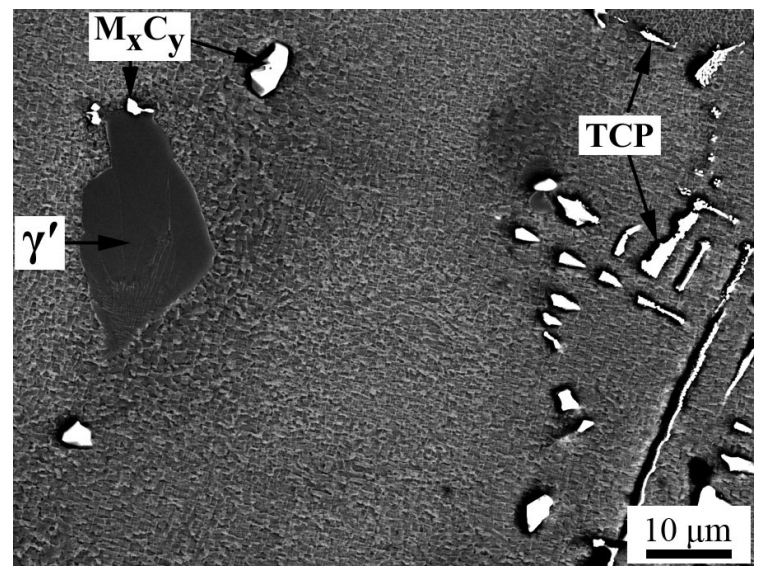

b

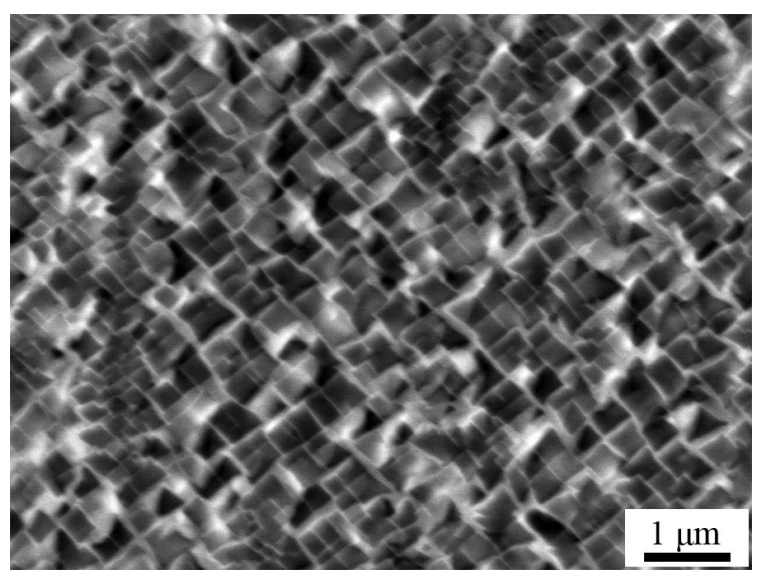

Fig. 1. BSE images of the superalloy in the as-cast condition at different magnifications: coarse primary $\gamma^{\prime}$ particles, carbides $\left(\mathrm{M}_{x} \mathrm{C}_{y}\right)$ and TCP phases are arrowed $(\mathrm{a}, \mathrm{b})$; dispersed $\gamma^{\prime}$ precipitates are observed (c). 


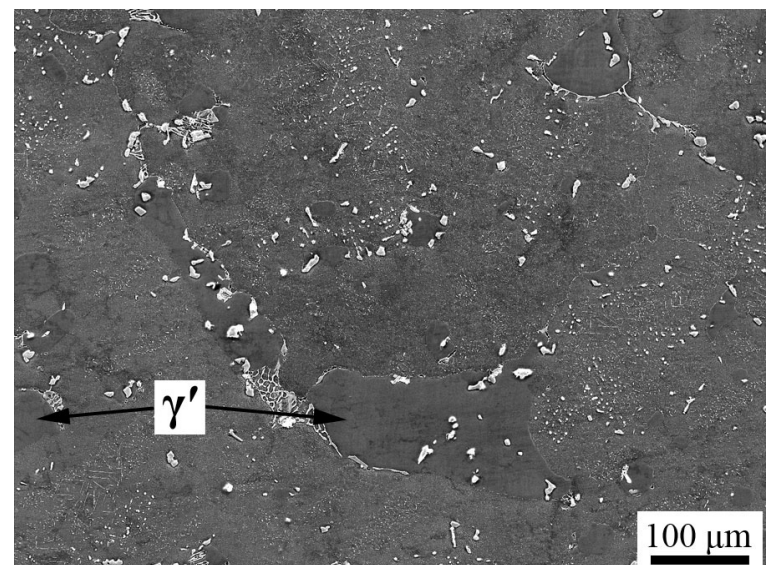

a

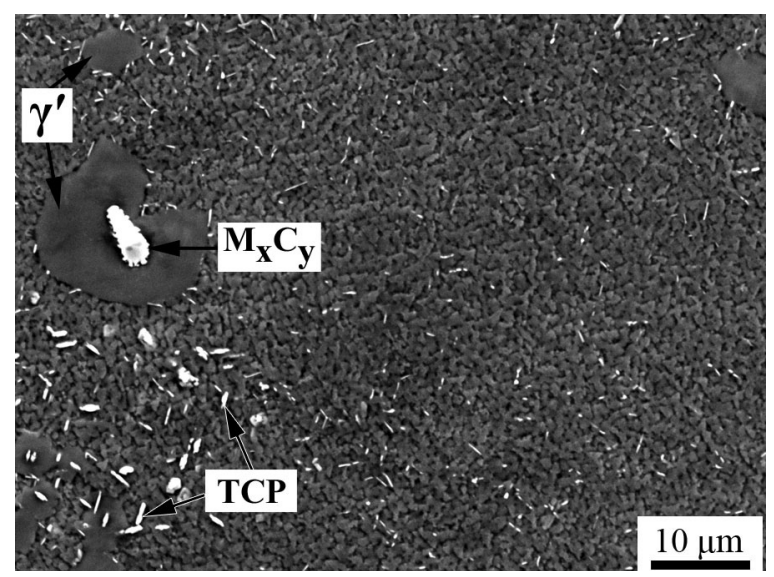

b

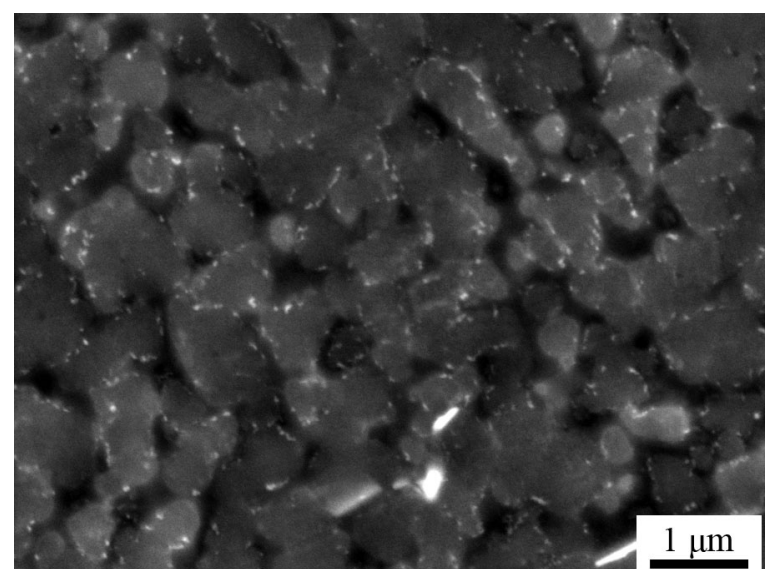

c

Fig. 2. BSE images of the superalloy in the cast and heat treated condition at different magnifications: coagulated primary $\gamma^{\prime}$ particles, carbides $\left(\mathrm{M}_{x} \mathrm{C}_{y}\right)$ and TCP phases are arrowed $(\mathrm{a}, \mathrm{b})$; fine white particles are probably the carbides precipitating during ageing $(c)$.

see that the superalloy under study demonstrated generally appreciably higher yield strength values at $900-1200^{\circ} \mathrm{C}$ in contrast to the other materials with the exception of VKNA-1V and VKNA-25 at $1200^{\circ} \mathrm{C}$ and VKNA-1VU at $1100^{\circ} \mathrm{C}$. At that the mentioned VKNA alloys had the yield strength values at $1200^{\circ} \mathrm{C}$ and $1100^{\circ} \mathrm{C}$ only slightly higher than those of the novel superalloy.

Thus, the new superalloy in spite of the presence of the coarse primary $\gamma^{\prime}$ particles showed quite competitive yield

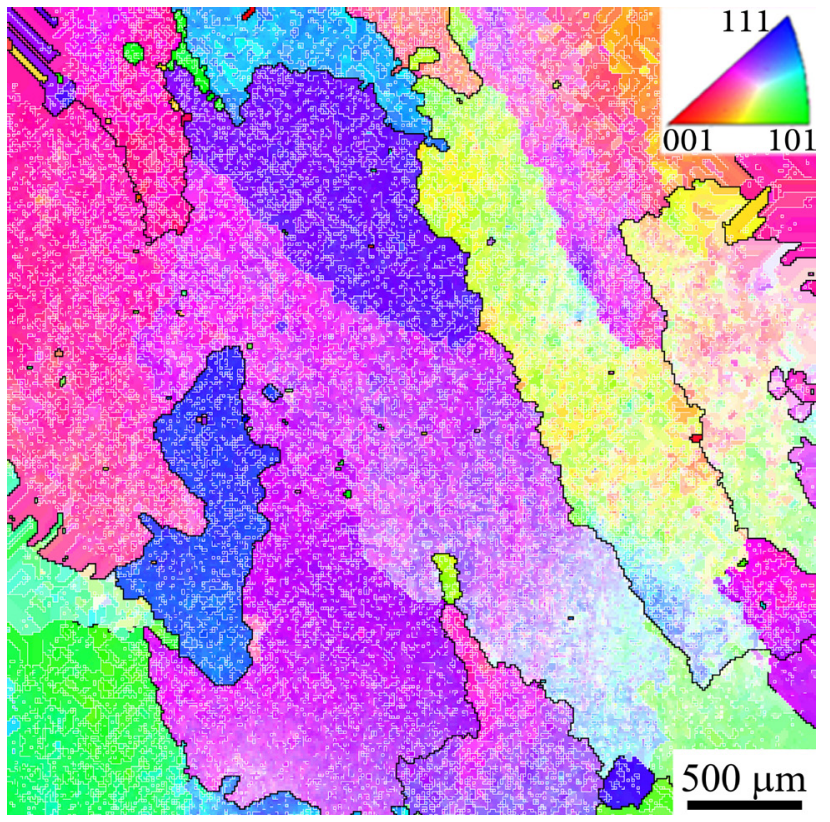

Fig. 3. (Color online) Normal-direction EBSD (inverse-pole-figure) map obtained for the novel superalloy in the cast and heat treated condition.

strength values at $900-1200^{\circ} \mathrm{C}$ as compared with known nickel base superalloys and even VKNA alloys based on the intermetallic $\mathrm{Ni}_{3} \mathrm{Al}$ phase. This was attained owing to higher alloying with the $\gamma^{\prime}$ forming elements ( $\mathrm{Al}, \mathrm{Ti}, \mathrm{Nb}$ and $\mathrm{Ta}$ ) and the substitution elements (Cr, Co, Mo, W, Re). Apparently, an important role played higher alloying with rhenium and tungsten. In further works it makes sense to specify the superalloy composition and to optimize the heat treatment conditions in order to minimize the coarse primary $\gamma^{\prime}$ phase content.

\section{Conclusions}

1. The novel superalloy $\mathrm{Ni}-13(\mathrm{Al}, \mathrm{Ti}, \mathrm{Nb}, \mathrm{Ta})-27(\mathrm{Cr}, \mathrm{Co}$, Mo, W, Re, Si, C, B) (wt.\%) has been designed as a potential die material for die forging of the most hard-to-deform nickel base superalloys. The novel superalloy was heavily alloyed with the $\gamma^{\prime}$ forming elements ( $\left.\mathrm{Al}, \mathrm{Ti}, \mathrm{Nb}, \mathrm{Ta}\right)$ and the substitution elements, particularly rhenium and tungsten. The superalloy microstructure included the $\gamma$ matrix, coarse primary $\gamma^{\prime}$ particles, fine $\gamma^{\prime}$ precipitates, and a small amount of carbides and TCP phases.

2. The microstructure examination suggests that the general solidification pathway was $L \rightarrow \gamma \rightarrow \gamma^{\prime}$, as it takes place in nickel base superalloys. The primary $\gamma^{\prime}$ particles were most probably formed via the peritectic reaction $L_{\text {noneq. }}+\gamma \rightarrow \gamma^{\prime}$, where $L_{\text {noneq. }}$ is the nonequilibrium liquid, which was retained at the peritectic temperature.

3. In spite of the fact that the superalloy in the heat treated condition had a coarse grained $\left(d_{\gamma} \sim 1 \mathrm{~mm}\right)$ structure containing about $15 \mathrm{vol} \%$ of the coarse primary $\gamma^{\prime}$ particles, the yield strength values under compression at $900-1200^{\circ} \mathrm{C}$ were generally higher as compared with those obtained for nickel base superalloys and the alloys based on the $\mathrm{Ni}_{3} \mathrm{Al}$ intermetallic phase. 


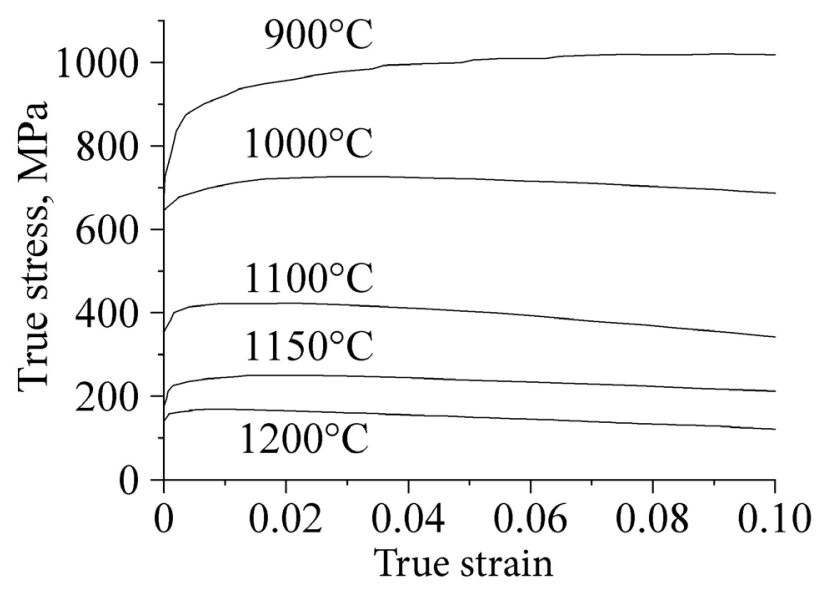

a

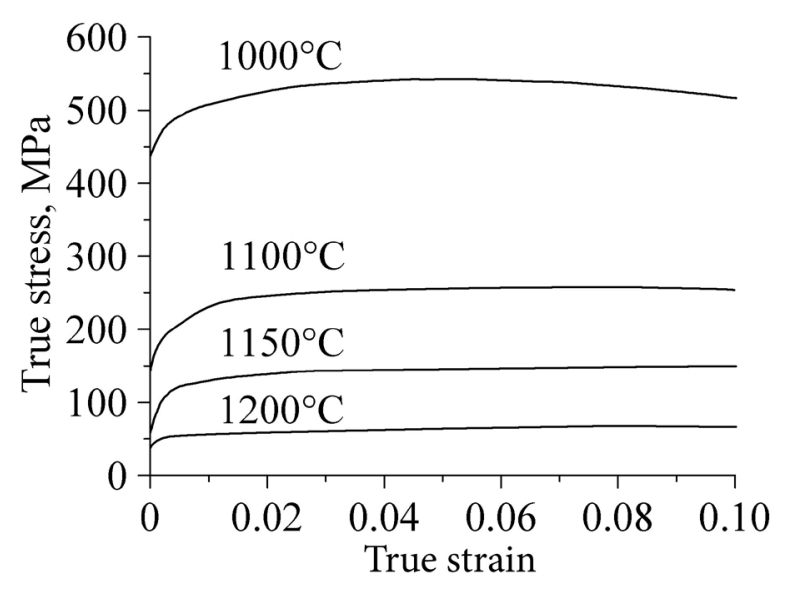

$\mathrm{b}$

Fig. 4. True stress-true strain curves obtained as a result of compression tests of samples of different superalloys: the superalloy under study (a), the SDZhS-15 superalloy alloyed with rhenium (b). The picture was redrawn from ref. [3].

Table 1. The temperature dependence of the yield strength $\left(\sigma_{0.2}\right)$ value of the novel superalloy in comparison with some nickel base superalloys and $\mathrm{Ni}_{3} \mathrm{Al}$ based alloys.

\begin{tabular}{|c|c|c|c|c|c|c|c|c|}
\hline \multirow{2}{*}{$\begin{array}{c}\text { Temperature, } \\
{ }^{\circ} \mathrm{C}\end{array}$} & \multicolumn{8}{|c|}{ Nickel base superalloys and the VKNA alloys based on the $\mathrm{Ni}_{3} \mathrm{Al}$ phase } \\
\hline & This study & SDZhS-15 [3] & ZhS6U [12] & VKNA-4 [6] & VKNA-1V [6] & VKNA-1VU [6] & VKNA-4U [6] & VKNA-25 [6] \\
\hline 900 & 841 & - & 746 & 615 & 560 & 790 & 580 & 660 \\
\hline 1000 & 674 & 471 & 510 & 290 & 430 & 575 & 430 & 510 \\
\hline 1100 & 404 & 198 & 298 & 215 & 350 & 430 & 370 & 370 \\
\hline 1150 & 228 & 107 & - & - & - & - & - & - \\
\hline 1200 & 160 & 45 & - & 115 & 185 & 145 & 150 & 170 \\
\hline
\end{tabular}

4. The superalloy composition and heat treatment conditions should apparently be slightly modified in order to minimize the content of the coarse primary $\gamma^{\prime}$ phase. After that the superalloy seems to be applicable as a die material for die forging of the most hard-to-deform nickel base superalloys.

Acknowledgements. The present work was supported by the Russian Science Foundation (Grant No. 18-19-00594). The work was performed using the facilities of the shared services center "Structural and Physical-Mechanical Studies of Materials" at the Institute for Metals Superplasticity Problems of Russian Academy of Sciences.

\section{References}

1. R.C. Reed. The superalloys: Fundamentals and Applications. Cambridge University Press (2006) 372 p. Crossref

2. H. Zhang, K. Zhang, S. Jiang, H. Zhou, C. Zhao, X. Yang. J. Alloys Compd. 623, 374 (2015). Crossref

3. Sh.Kh. Mukhtarov, V.M. Imayev, A.V. Logunov, Yu. N. Shmotin, A.M. Mikhailov, R.A. Gaisin, R. V. Shakhov, A. A. Ganeev, R. M. Imayev. Mater. Sci. \& Technol. 35 (13), 1605 (2019). $\underline{\text { Crossref }}$

4. V.M. Imayev, S.K. Mukhtarov, A. V. Logunov,
A. A. Ganeev, R. V. Shakhov, R. M. Imayev. Letters on Materials. 9 (2), 249 (2019) (in Russian). Crossref

5. A. A. Ganeev, V. A. Valitov, F.Z. Utyashev, V.M. Imayev. The Physics of Metals and Metallography. 120 (4), 442 (2019). (in Russian) Crossref

6. E. N. Kablov, O. G. Ospennikova, O.A. Bazyleva. Vestnik MGTU im N.E. Baumana. Ser. "Mashinostroenie", 13, (2011). (in Russian)

7. K.B. Povarova, N.K. Kazanskaya, V.P. Buntushkin, V.G. Kostogryz, V.G. Bakharev, V.I. Mironov, O. A. Bazyleva, A.A. Drozdov, I. O. Bannykh. Russian metallurgy (Metally). 3, 269 (2003).

8. J. Schramm. Z. Metallkd. 33, 347 (1941).

9. I. Ansara, N. Dupin, H.L. Lukas, B. Sundman. J. Alloys Compd. 247, 20 (1997). Crossref

10. E.B. Chabina, N.V. Petrushin, M.B. Bronfin, L. A. Dyachkova. Russian metallurgy (Metally). 3, 85 (1994). (in Russian)

11. E. N. Kablov, O. G. Ospennikova, O. A. Bazyleva. Dvigatel. 4 (70), 22 (2010). (in Russian)

12. O.G. Ospennikova. Razrabotka nauchnykh osnov sozdaniya novogo pokoleniya liteinykh jaroprochnykh nanostrukturirovannykh nikelevykh splavov ponijennoi plotnosti s trebuemym kompleksom mekhanicheskikh svoistv: Dissertacija na soiskanie stepeni doktora tehnicheskih nauk. Moskva (2018) 321 p. (in Russian). 